\title{
Pengaruh Return on Equity, Debt to Equity Ratio, Fixed Asset Turnover, Price to Book Value dan Interest Rate terhadap Price Earning Ratio pada Perusahaan Property \& Real Estate di Bursa Efek Indonesia
}

\author{
Agung Setiyawan ${ }^{1}$, Oman Rusmana $^{2}$ \\ ${ }^{1}$ Universitas Pancasila, Jl. Srengseng Sawah, Jagakarsa, Jakarta Selatan 12640 \\ ${ }^{2}$ Universitas Jenderal Soedirman, Jl. Prof. Dr. HR. Boenyamin No. 107,Purwokerto 53122 Jawa Tengah
}

I N F O A R T I KEL

\author{
JEL Classification: \\ G14 \\ G30
}

\section{Keywords:}

Return on Equity, Debt to

Equity Ratio, Fixed Assets

Turnover Price to Book

Value \& Price Earning

Ratio.

\section{A B S TR A C T}

This study is aimed to examine the influence return on equity (ROE), debt to equity ratio (DER), fixed assets turnover (FATO), price to book value (PBV) and interest rate (IR) towards price earning ratio (per). Population of this study are Property \& Real Estate companies which had go public in Indonesia Stock Exchange (IDX) during the period of 2008-2012.This research take 11 samples of 52 Property \& Real Estate companies listed in IDX during the period of 2008-2012. This research concluded that the price to book value (PBV) and interest rate (IR) have significant influence towards the price earning ratio (PER). Meanwhile, other variables partially have no significant influence towards the price earning ratio (PER).

\begin{abstract}
A B S T RA K
Penelitian ini dilakukan untuk menguji pengaruh return on equity (ROE), debt to equity ratio (DER), fixed assets turnover (FATO), price to book value (PBV) dan interest rate (IR) terhadap Price Earning Ratio (PER). Populasi penelitian adalah perusahaanperusahaan Property \& Real Estate yang terdaftar di Bursa Efek Indonesia (BEI) selama periode 2008-2012. Penelitian ini mengambil jumlah sampel sebanyak 14 perusahaan dari 52 perusahaan Property \& Real Estate yang terdaftar di BEI selama periode 2008-2012. Hasil penelitian menunjukkan bahwa variabel Price to Book Value (PBV) dan Interest Rate (IR) secara parsial berpengaruh signifikan terhadap Price Earning Ratio (PER). Sedangkan Return on Equity (ROE), Debt to Equity Ratio (DER) dan Fixed Assets Turnover (FATO) tidak berpengaruh signifikan terhadap Price Earning Ratio (PER).
\end{abstract}

\section{Pendahuluan}

Perkembangan fundamental perekonomian di Indonesia selama lima tahun terakhir (2007-2011) menunjukkan hal-hal yang patut dibanggakan walaupun kondisi ekonomi global sedang mengalami krisis yang dipicu oleh sub prime mortgage di Amerika Serikat tahun 2008 dan krisis hutang di zona Eropa khususnya Yunani tahun 2009 sampai sekarang (Adi, 2013). Kondisi tersebut di atas tentu 
harus dapat dimanfaatkan dengan maksimal oleh tiap pihak, salah satunya adalah investor melalui investasi pada surat berharga terutama saham dengan maksimal. Analisis fundamental mengenal 2 cara dalam menghitung nilai intrinsik saham yaitu pendekatan nilai sekarang (pendekatan present value) dan pendekatan PER (Price Earning Ratio) (Jogiyanto 2010 : 131).

Menurut Tambunan (2007:245), PER merefleksikan penilaian investor atas pertumbuhan keuntungan, risiko dan efisiensi, serta kondisi keuangan perusahaan dalam satu paket rasio yang sederhana. Untuk investor, rasio PER yang rendah akan memberikan penilaian tersendiri sebab dapat membeli saham dengan harga yang relatif murah selain itu juga memiliki potensi untuk mendapatkan capital gain. Untuk emiten sebaliknya, mereka menginginkan rasio PER yang tinggi untuk menunjukkan bahwa kinerja perusahaan cukup baik dan mempunyai prospek yang baik di masa depan sehingga diharapkan agar harga saham akan tinggi pula. Hal tersebut menunjukkan kondisi anomali sebab suatu emiten yang mempunyai PER yang tinggi menunjukkan prospek yang baik di masa depan sehingga diharapkan return yang didapat akan tinggi namun dari sisi investor cenderung lebih menyukai emiten dengan PER yang rendah. Kondisi anomali pasar dalam teori keuangan sedikitnya ada 4 macam yaitu anomali perusahaan, anomali peristiwa, anomali musiman dan anomali akuntansi, Widyastuti (2008). Menurut Brealy dan Myers (2008) PER yang tinggi menunjukkan bahwa perusahaan memiliki peluang pertumbuhan yang baik dimasa mendatang, memiliki tingkat laba yang relatif aman dan menandakan tingkat kapitalisasi yang tinggi. Rasio PER yang tinggi mengindikasikan bahwa investor berharap akan pertumbuhan deviden yang tinggi dan risiko saham yang rendah, oleh karena itu, menurut Brealy \& Myers faktor utama yang paling berpengaruh terhadap PER adalah tingkat pertumbuhan deviden dan risiko perusahaan

$$
\text { Penelitian-penelitian terdahulu }
$$

mengenai Price Earning Ratio ( $\mathrm{P} / \mathrm{E}$ ratio) telah banyak dilakukan. Penelitian mengenai $\mathrm{P} / \mathrm{E}$ ratio pada tahap awal dilakukan oleh Nicolson (1960), yang mengemukakan bahwa perusahaan dengan PER rendah secara ratarata menghasilkan return yang lebih tinggi dibandingkan perusahaan dengan PER tinggi. Dari hasil penelitian Nicolson maka investor seharusnya membeli saham perusahaan yang memiliki PER yang rendah. Hasil penelitian tersebut kemudian juga diperkuat oleh penelitian selanjutnya yang dilakukan oleh Basu $(1975,1977)$. Whitbeck \& Kissor (1963) mengemukakan bahwa dividend payout, earning growth memiliki hubungan positif terhadap PER risk berhubungan negatif. Beaver \& Morse (1978) mengemukakan bahwa penjelasan yang paling mungkin terhadap faktor-faktor yang menentukan PER bukan pertumbuhan maupun risiko namun perbedaan dalam metode akuntansi. Pada beberapa periode terakhir ini penelitian lebih difokuskan pada PER sebagai variabel yang bersifat menjelaskan dibandingkan pengaruh anomalinya, misal penelitian yang dilakukan oleh Mpaata dan Sartono (1997), mereka meneliti dengan menggunakan data perusahaan Amerika dengan menggunakan tujuh variabel yaitu penjualan, size, dividend payout ratio, aktiva tetap, leverage, ROE dan pertumbuhan laba. Hasil penelitian menunjukkan bahwa ketujuh variabel tersebut berpengaruh secara signifikan dan konsisten untuk enam jenis industri yang berbeda

Penelitian lain dilakukan oleh AmoakoAdu dan Smith (2002), mereka meneliti hubungan antara tingkat bunga dan PER pada bursa efek Kanada, hasilnya menunjukkan terdapat hubungan negatif antara tingkat bunga dan PER yaitu pada saat tingkat suku bunga naik maka PER ratio akan turun dan sebaliknya. Sementara, Tian \& Zheng (2006) meneliti data pada bursa efek Shanghai dan hasil penelitian menunjukkan bahwa turn over rate of total asset,dividen growth rate, return on net asset mempunyai hubungan negatif terhadap PER. Datar \& Banarjee (2006) juga melakukan penelitian di bursa efek India dan hasil penelitian menunjukkan bahwa marjin penjualan yang tinggi berhubungan negatif terhadap PER. Penelitian lainnya juga dilakukan oleh Kulling dan Lunberg (2007), yang meneliti data pada bursa efek Swedia dengan sembilan kelompok industri yang berbeda, penelitian ini menggunakan tujuh variabel yaitu dividend yield, interest rate, risk, growth, debt to equity, market value dan market to book value. Hasil penelitian menunjukkan bahwa lima dari tujuh variabel penelitian yaitu interest rate, risk, debt to equity, market value dan market to book value memiliki pengaruh yang signifikan pada sembilan industri yang berbeda. 
Fenomena penggunaan analisis fundamental dalam pengambilan keputusan investasi sudah lazim bagi para investor maupun analis sekuritas. Penelitian - penelitian terdahulu mengenai PER telah banyak dilakukan diantaranya adalah Mpaata \& Sartono (1997), Amoako-Adu \& Smith (2002), Kurniawan (2005), Wiwin,et.al (2005), Yumettasari,et. al (2006), Kulling \& Lunberg (2007), Hayati (2009), Hamidah (2009), Faezinia, et.al, Aji \& Pangestuti (2012), Arisona (2013). Penelitianpenelitian terdahulu tersebut mempunyai hasil yang berbeda-beda. Oleh sebab itu maka penulis tertarik untuk melakukan penelitian kembali terhadap variabel-variabel yang memengaruhi PER. Perbedaan dengan penelitian terdahulu adalah dalam penelitian ini terletak pada obyek dan periode penelitian yang digunakan. Dari uraian tersebut penelitian ini bertujuan menemukan bukti empiris terkait pengaruh return on equity, debt to equity ratio, fixed assets turnover, price to book value dan interest rate terhadap price earning ratio pada perusahaan property \& real estate yang terdaftar di Bursa Efek Indonesia periode 2008 - 2012 diharapkan hasil penelitian dapat bermanfaat bagi beberapa pihak baik penelti, investor, perusahaan \& akademisi.

\section{Telaah Teori dan Pengembangan Hipotesis}

\subsection{Agency Theory}

Teori Keganen yaitu dimana Pihak manajemen sebagai pihak yang diberi tanggungjawab untuk mengelola perusahaan akan berusaha dengan segenap kemampuan yang dimiliki dan sumber daya yang ada untuk memperoleh keuntungan secara maksimal. Dari keuntungan inilah yang akan menjadi dasar dalam meningkatkan kekayaan pemilik perusahaan (pemegang saham) melalui pembayaran dividen yang dilakukan perusahaan. Apabila pemilik perusahaan berbeda dengan pengelola maka akan menimbulkan masalah dalam pencapaian tujuan perusahaan yaitu memaksimalkan kekayaan pemilik.

Tujuan dari perusahaan adalah untuk memaksimalkan kekayaan pemilik .Pihak manajemen sebagai pihak yang diberi tanggungjawab untuk mengelola perusahaan akan berusaha dengan segenap kemampuan yang dimiliki dan sumber daya yang ada untuk memperoleh keuntungan secara maksimal. Dari keuntunganinilahyangakanmenjadidasardalam meningkatkan kekayaan pemilik perusahaan (pemegang saham) melalui pembayaran dividen yang dilakukan perusahaan. Apabila pemilik perusahaan berbeda dengan pengelola maka akan menimbulkan masalah dalam pencapaian tujuan perusahaan yaitu memaksimalkan kekayaan pemilik. Perbedaan antara pihak yang bertindak sebagai pemilik dan pengelola akan menimbulkan konsekuensi pemisahaan antara pihak yang bertindak sebagai pengawas dan pihak yang diawasi. Perbedaan tersebut memerlukan suatu hubungan yang disebut dengan hubungan agensi dalam perusahaan. Jika manajer tidak melaksanakan pekerjaan sesuai dengan harapan atau keinginan pemilik maka akan menimbulkan masalah dalam pengelolaan perusahaan (organisasi) yang disebut dengan masalah keagenan (agency problem).

\subsection{Signalling Theory}

Informasi yang dipublikasikan sebagai pengumuman akan memberikan sinyal bagi investor dalam pengambilan keputusan investasi, Jogiyanto (2000). Pasar diharapkan akan merespon dengan baik pada saat pengumuman diterima apabila bernilai positif. Menurut Thiono dalam Saerang (2011), signalling theory menjelaskan mengapa perusahaan mempunyai dorongan untuk memberikan informasi laporan keuangan pada pihak eksternal. Pihak perusahaan memberikan informasi karena terdapat asimetri informasi antara pihak perusahaan dengan pihak luar. Informasi asimetri merupakan suatu keadaan dimana salah satu pihak mempunyai informasi yang lebih banyak dibandingkan dengan pihak yang lain. Perusahaan dapat meningkatkan nilai perusahaan dengan mengurangi informasi asimetri. Salah satu cara untuk mengurangi informasi asimetri adalah dengan memberikan sinyal ke pihak luar. Sinyal berupa publikasi informasi keuangan yang dipercaya akan mengurangi ketidakpastian mengenai prospek perusahaan di masa yang akan datang.

\subsection{Efficient Market Hypothesis (EMH)}

Harga sekuritas pada dasarnya dapat merefleksikan secara tepat kemampuan untuk memproses suatu informasi dan pengetahuan yang dimiliki oleh investor. Dalam konsep efisiensi pasar, suatu pasar disebut efisien jika harga-harga yang terbentuk di pasar merupakan cerminan dari seluruh informasi yang ada. 
Jogiyanto (2010) mengemukakan bahwa efisiensi pasar dapat dikelompokkan dalam 2 jenis yaitu efisiensi pasar secara informasi (informationally efficient market) dan efisiensi pasar secara keputusan (decisionally efficient market). Menurut Fama (1970), tingkat efisiensi pasar ditinjau dari ketersediaan informasi ada tiga yaitu, The weak form market efficient, the semistrong market efficient, The strong efficient market lalu Jogityanto menambah dengan The Decisionally market efficient.

\subsection{Market Anomaly}

Keanomalian pada konteks ini berhubungan dengan hipotesis pasar efisien dimana keefisienan market terkait dengan ketersediaan informasi, apakah bisa merefleksikan nilai atau harga sebenarnya pada sekuritas tersebut atau tidak. Menurut teori keuangan dikenal sedikitnya empat macam anomali pasar seperti dalam tabel berikut ini:

Tabel 1

Klasifikasi Anomali Pasar

\begin{tabular}{ccll}
\hline No & Kelompok & \multicolumn{1}{c}{ Contoh } & \multicolumn{1}{c}{ Keterangan } \\
\hline 1 & Anomali Peristiwa & $\begin{array}{l}\text { Analysts } \\
\text { Recommedation }\end{array}$ & $\begin{array}{l}\text { Harga saham semakin tinggi peluang untuk turun } \\
\text { apabila banyak analis yang merekomendasikan } \\
\text { untuk membeli suatu saham }\end{array}$ \\
2 & Anomali Musiman & January & $\begin{array}{l}\text { Harga sekuritas cenderung naik pada bulan Januari di } \\
\text { hari-hari pertama }\end{array}$ \\
3 & Anomali Perusahaan & Size & $\begin{array}{l}\text { Perusahaan kecil cenderung untuk memiliki return } \\
\text { yang lebih tinggi }\end{array}$ \\
& Anomali Akuntansi & PER & $\begin{array}{l}\text { Saham dengan PER rendah cenderung memilki return } \\
\text { yang lebih tinggi }\end{array}$ \\
\hline
\end{tabular}

\subsection{Price Earning Ratio (PER)}

Price Earning Ratio (PER) adalah rasio yang membandingkan antara harga per lembar saham terhadap laba per lembar saham. (Bodie, et. al 2006 : 241). PER dapat diformulasikan sebagai Market price per share/Earning per share. Rasio ini juga merefleksikan penilaian investor atas pertumbuhan keuntungan, risiko, efisiensi dan kondisi keuangan perusahaan. PER dapat diformulasikan sebagai berikut:

$\mathrm{PER}=$ Market price per share Earning per share

Sedangkan Earning per share (EPS) diformulasikan sebagai berikut:

$\mathrm{EPS}=\underline{\text { Net Income }}$ Outstanding Shares

\subsection{Return on Equity (ROE)}

ROE merupakan bagian dari indikator rasio profitabilitas yang menjadi perhatian pihak investor. Menurut Palepu (2010), Return on Equity merupakan indikator komprehensif dari performance suatu perusahaan sebab mengindikasikan seberapa baik manajer menggunakan sumberdaya yang diinvestasikan oleh pemegang saham untuk mendapatkan return. Return on Equity (ROE) diformulasikan sebagai berikut :

$$
\text { ROE }=\frac{\text { Net income }}{\text { Equity }}
$$

\subsection{Debt to Equity Ratio (DER)}

Rasio ini merupakan indikator untuk mengukur seberapa besar utang yang dimiliki perusahaan atas equity (modal sendiri) atau merupakan perbandingan antara total liabilities dengan total equity yang digunakan dalam pendanaan usaha. Debt to Equity Ratio (DER) diformulasikan sebagai berikut:

$$
\text { DER }=\frac{\text { Total Liabilities }}{\text { Total Equity }}
$$

\subsection{Fixed Asset Turn Over (FATO)}

Salah satu kunci perusahaan untuk meraih keuntungan adalah seberapa baik perusahaan dalam mengelola dan memanfaatkan asset yang dimiliki. Rasio Fixed Asset Turn Over merupakan bagian dari rasio 
aktivitas dimana menurut Harjito (2012) rasio aktivitas merupakan rasio yang mengukur sejauh mana efektivitas manajemen perusahaan dalam mengelola asset-assetnya. Rasio Fixed Asset Turn Over digunakan untuk mengukur efektivitas perusahaan dalam menggunakan aktiva tetapnya untuk memperoleh penjualan. Fixed asset turnober (FATO) diformulasikan sebagai berikut:

FATO $=\underline{\text { Sales }}$

Fixed Asset

\subsection{Price to Book Value (PBV)}

Harga dan nilai buku merupakan suatu faktor yang menarik bagi pihak investor. Apabila harga jual saham di bawah nilai buku artinya saham tersebut mengalami undervalue dan sebaliknya. Price to Book Value (PBV) diformulasikan sebagai berikut :

$$
\text { Price to Book Value (PBV) }
$$

diformulasikan sebagai berikut:

$$
\begin{aligned}
\mathrm{PBV} & =\frac{\text { Market price per share }}{\text { Book Value Per Share }} \\
\mathrm{BV} & =\frac{\text { Equity }}{\text { Outstanding Shares }}
\end{aligned}
$$

\subsection{Interest Rate (IR)}

Menurut Rose \& Marquis interest rate pada intinya merupakan merupakan suatu pembayaran harga yang harus dilakukan oleh peminjam atas penggunaan sejumlah dana dari pemberi pinjaman dalam jangka waktu yang disepakati. Apabila terjadi perubahan tingkat bunga pada suatu negara menurut Madura (2012) akan terjadi perubahan jumlah investasi suatu negara baik investor lokal maupun asing khususnya untuk jenis investasi portofolio (dalam hal ini investasi di pasar modal). Jika tingkat suku bunga rendah maka meminjam dana menjadi mudah dan tingkat surat bunga menjadi kecil. Ukuran tingkat suku bunga dalam hal ini adalah dengan menggunakan data tingkat suku bunga Sertifikat Bank Indonesia (SBI), yang merupakan instrumen investasi jangka pendek yang dikeluarkan oleh Bank Indonesia dimana fungsi utamanya adalah untuk menjaga stabilitas moneter. BI akan menyerap likuiditas (uang yang beredar di masyarakat) dengan menerbitkan SBI (yang dilakukan melalui mekanisme lelang) sehingga nilai tukar rupiah dapat terkendali. Pembeli SBI umumnya adalah kalangan investor asing dan domestik, seperti asuransi, dana pensiun dll. Data yang akan dipergunakan adalah SBI 30

\begin{tabular}{|c|c|c|c|c|}
\hline No. & Peneliti & $\begin{array}{l}\text { Objek } \\
\text { Penelitian }\end{array}$ & Judul & Hasil \\
\hline 1 & $\begin{array}{l}\text { Whitbeck \& } \\
\text { Kissor } \\
(1963)\end{array}$ & $\begin{array}{l}\text { Index Standard } \\
\text { \& Poors } 500 \\
(1958-1960)\end{array}$ & $\begin{array}{l}\text { A New Tool } \\
\text { in Investment } \\
\text { Decision } \\
\text { Making }\end{array}$ & $\begin{array}{l}\text { Projected growth rate, anticipated } \\
\text { standard deviation \& prospective ratio } \\
\text { of dividend to earning berpengaruh } \\
\text { terhadap PER }\end{array}$ \\
\hline 2 & $\begin{array}{l}\text { Beaver \& } \\
\text { Morse (1978) }\end{array}$ & $\begin{array}{l}\text { Perusahaan di } \\
\text { berbagai sektor } \\
\text { pada NYSC } \\
(1956-1974)\end{array}$ & $\begin{array}{l}\text { What } \\
\text { Determines The } \\
\text { Price Earnings } \\
\text { Ratio? }\end{array}$ & $\begin{array}{l}\text { Dividend payout ratio, growth in } \\
\text { earning per share, risk less rate, } \\
\text { change in accounting method } \\
\text { berpengaruh terhadap PER }\end{array}$ \\
\hline
\end{tabular}
maksudnya tingkat bunga investasi SBI untuk periode 1 bulan. Beberapa

Tabel 2

Penelitian Terdahulu

\subsection{Hipotesis}

Berdasarkan landasan teori yang dikembangkan dari latar belakang permasalahan yang disesuaikan dengan tujuan penelitian dan rerangka pemikiran teoritas maka dapat dirumuskan hipotesis alternatif sebagai berikut:
$\mathrm{H}_{1}$ : Return on Equity (ROE), Debt to Equity Ratio (DER), Fixed Assets Turnover (FATO), Price to Book Value (PBV) dan Interest Rate (IR) secara simultan berpengaruh secara signifikan terhadap Price Earning Ratio (PER) 
$\mathrm{H}_{2}:$ Return on Equity (ROE) berpengaruh positif terhadap Price Earning Ratio (PER).

$\mathrm{H}_{3}$ : Debt to Equity Ratio (DER) berpengaruh negatif terhadap terhadap Price Earning Ratio (PER)

$\mathrm{H}_{4}$ : Fixed Assets Turnover (FATO) berpengaruh positif terhadap Price Earning Ratio (PER).

$\mathrm{H}_{5}$ : Price to Book Value (PBV) berpengaruh positif terhadap Price Earning Ratio (PER).

$\mathrm{H}_{6}$ : Interest Rate (IR) berpengaruh negatif terhadap Price Earning Ratio (PER).

\section{Metode Penelitian}

Penelitian ini menggunakan data sekunder yang diambil dari berbagai sumber melalui studi kepustakaan, yaitu dengan mempelajari berbagai bacaan atau dokumen yang terkait erat dengan masalah penelitian, baik berupa artikel dan literatur ilmiah maupun data laporan. Sumber data antara lain diperoleh dari ICMD (Indonesia Capital Market Directory), Bursa Efek Indonesia (www.idx.co.id) dan Bank Indonesia (www.bi.go.id) Penelitian ini menggunakan data gabungan antara data time series and cross section.

Populasi penelitian ini adalah sahamsaham perusahaan sektor property \& real estate yang terdaftar di Bursa Efek Indonesia dengan tahun pengamatan selama periode tahun 2008 sampai dengan 2012. Penentuan sampel dalam penelitian ini menggunakan teknik purposive sampling. Dari kriteria tersebut didapatkan 11 perusahaan yang memenuhi persyaratan.

Metode analisis yang digunakan untuk menguji hipotesis adalah regresi linier berganda untuk menganalisis hubungan antar variabel yaitu variabel dependen (Y) dan variabel independen $(\mathrm{X})$. Persamaan model regresi adalah sebagai berikut.

$$
\begin{aligned}
\mathrm{Y}= & \alpha+\beta_{1} \mathrm{ROE}+\beta_{2} \mathrm{DER}+\beta_{3} \mathrm{FATO}+\beta_{4} \\
& \mathrm{PBV}+\beta_{5} \mathrm{IR}+\varepsilon
\end{aligned}
$$

Keterangan :

$$
\begin{array}{ll}
\mathrm{Y} & =\text { Price Earning Ratio } \\
\mathrm{A} & =\text { Konstanta } \\
\beta_{1}-\beta_{5} & =\text { Koefisen Regresi } \\
\mathrm{ROE} & =\text { Return on Equity } \\
\mathrm{DER} & =\text { Deby to Equity Ratio } \\
\mathrm{FATO} & =\text { Fixed Asset Turn Over } \\
\mathrm{PBV} & =\text { Price Book Value }
\end{array}
$$

$$
\begin{array}{ll}
\mathrm{IR} & =\text { Interest Rate } \\
\mathrm{E} & =\text { Error }
\end{array}
$$

Asumsi Klasik

$$
\text { Pengujian data menggunakan Uji }
$$

1. Uji Normalitas

Uji normalitas dilakukan untuk mengetahui apakah dalam model regresi antara variabel dependen dan independen keduanya memilki distribusi normal atau tidak. Diasumsikan bahwa nilai residual mengikuti distribusi normal. Menurut Ghozali (2005) dalam Abdurrakhman (2012) ada 2 cara untuk mendeteksi apakah residual berdistribusi normal atau tidak yaitu analisis grafik dan uji komlmogoriv-Smirov.

2. Uji Multikolinieritas

Uji multikolinieritas bertujuan untuk menguji apakah dalam model regresi yang terbentuk ada korelasi yang tinggi atau sempurna diantara variabel bebas atau tidak. Uji multikolinieritas dapat dilakukan dengan cara sebagai berikut yaitu dengan mendeteksi nilai VIF. jika VIF $>10$ berarti antar variabel independen memiliki multikolinieritas dan dengan mendeteksi nilai Tolerance, jika nilai Tolerance di atas 0.10 maka antar variabel independen tidak memiliki masalah multikolinieritas.

3. Uji Heteroskedastisitas

Uji heteroskedastisitas bertujuan untuk menguji apakah dalam model regresi terjadi ketidaksamaan varians dari residual suatu pengamatan ke pengamatan lainnya. Menurut Ghozali (2009) dalam Abdurrakhman (2012), ada 2 cara untuk mendeteksi ada masalah heteroskedastisitas, yaitu dengan metode grafik \& Uji Statistik Heteroskedastisitas dengan uji Spearman's Rho. Apabila nilai signifikansi korelasi di bawah 0.05 maka dalam model regresi terdapat heteroskedastisitas.

4. Uji Autokorelasi

Uji autokorelasi bertujuan untuk mengetahui apakah ada korelasi antara anggota serangkaian data observasi yang diuraikan menurut waktu (times-series) dan ruang (cross section). Penelitian ini menggunakan uji Durbin-Watson (DW test) dalam mendeteksi autokorelasi. Menurut Ghozali (2009) dalam Abdurrakhman (2012).

Pengujian Hipotesis terdiri dari :

1. Uji F Statistik (Simultan)

Bertujuan untuk menguji apakah antar 
variabel independen secara bersama-sama berpengaruh signifikan atau tidak terhadap variabel dependen. Dilakukan dengan dengan membandingkan nilai Ftabel (dengan tingkat signifikansi $\alpha=5 \%$ ) dengan nilai Fhitung. Jika Fhitung $>$ Ftabel maka secara simultan hipotetis penelitian diterima.

2. Uji t (Parsial)

Bertujuan untuk menguji pengaruh variabel independen secara parsial terhadap variabel dependen. Apabila nilai thitung $>$ ttabel (pada taraf signifikansi $\alpha=5 \%$ ), artinya variabel independen berpengaruh ignifikan terhadap variabel dependen.

3. Koefisien Determinasi (R2) Nilai Koefisien Determinasi(R2) ini berkisar antara 0 dan $1(0<\mathrm{R} 2<1)$. Apabila nilai $\mathrm{R} 2$ maka hubungan kedua variabel tersebut kuat atau dengan kata lain model tersebut dapat menerangkan kondisi yang sebenarnya.

\section{Hasil Penelitian Dan Pembahasan}

Tabel 3

Statistik Deskriptif Variabel

Perusahaan Sektor Property \& Real Estate Tahun 2008-2012

\begin{tabular}{llllll}
\hline & N & Minimum & Maximum & Mean & Std. Deviation \\
\hline PER & 55 & .58 & 34.15 & 11.9307 & 8.44144 \\
ROE & 55 & .02 & .33 & .1251 & .07177 \\
DER & 55 & .28 & 3.11 & 1.5213 & .73018 \\
FATO & 55 & .80 & 100.86 & 15.2629 & 17.93036 \\
PBV & 55 & .13 & 3.84 & 1.3091 & .96220 \\
IR & 55 & .06 & .09 & .0720 & .00989 \\
Valid N (listwise) & 55 & & & & \\
\hline
\end{tabular}

Analisa:

- Perusahaan sektor property \& real estate selama periode 2008-2012 mempunyai nilai PER rata-rata sebesar 11.9307. Diantara perusahaan-perusahaan tersebut ada yang mempunyainilai minimum sebesar 0.58 yaitu PT Gowa Makasar Tourism Development, tbk sedangkan yang mempunyai nilai PER maksimum adalah PT Summarecon Agung, tbk dengan nilai sebesar 34.15. Perbedaan antara PER dengan nilai maksimum dan minimum dari $0.58 \mathrm{~s} / \mathrm{d} 34.15$ menunjukkan bahwa PER antar perusahaan bervariasi cukup tinggi. Sedangkan nilai standar deviasi antar perusahaan-perusahaan tersebut adalah sebesar 8.44144.

- Perusahaan sektor property \& real estate selama perioden 2008-2012 mempunyai nilai ROE rata-rata sebesar 0.1251. Diantara perusahaan-perusahaan tersebut mempunyai nilai minimum sebesar 0.02 yaitu PT Duta Pertiwi, tbk, sedangkan yang nilai ROE maksimum adalah PT Lippo Cikarang, tbk dengan nilai sebesar 0.33 . Perbedaan antara ROE dengan nilai maksimum dan minimum dari $0.02 \mathrm{~s} / \mathrm{d} 0.33$ menunjukkan bahwa
ROE antar perusahaan bervariasi cukup tinggi. Sedangkan nilai standar deviasi antar perusahaan-perusahaan tersebut adalah sebesar 0.07177 .

- Perusahaan di sektor property \& real estate selama periode tahun 2008-2012 mempunyai nilai DER rata-rata sebesar 1.5213. Diantara perusahaan-perusahaan tersebut mempunyai nilai minimum sebesar 0.28 yaitu PT Duta Pertiwi, tbk nilai DER maksimum adalah PT Wijaya Karya, tbk dengan nilai sebesar 3.11. Perbedaan antara DER dengan nilai maksimum dan minimum dari $0.28 \mathrm{~s} / \mathrm{d} 3.11$ menunjukkan bahwa ROE antar perusahaan bervariasi cukup tinggi. Sedangkan nilai standar deviasi antar perusahaan-perusahaan tersebut sebesar 0.73018 .

- Perusahaan di sektor property \& real estate selama periode 2008-2012 mempunyai nilai FATO rata-rata sebesar 15.2629. Diantara perusahaan-perusahaan tersebut mempunyai nilai minimum sebesar 0.80 yaitu PT Ciputra Surya, tbk- sedangkan yang mempunyai nilai FATO maksimum adalah PT Gowa Makasar Tourism Development, tbk dengan nilai sebesar 100.86. Perbedaan antara FATO 
dengan nilai maksimum dan minimum dari $0.80 \mathrm{~s} / \mathrm{d} 100.86$ menunjukkan bahwa FATO antar perusahaan bervariasi cukup tinggi. Sedangkan nilai standar deviasi antar perusahaan-perusahaan tersebut adalah sebesar 17.93036.

- Perusahaan di sektor property \& real estate selama periode pengamatan dari tahun 2008-2012 punya nilai PBV ratarata sebesar 1.3091. Diantara perusahaanperusahaan tersebut mempunyai nilai minimum sebesar 0.13 yaitu PT Ciputra Surya, tbk sedangkan yang mempunyai nilai PBV maksimum adalah PT Gowa Makasar Tourism Development, tbk dengan nilai sebesar 3.84. Perbedaan antara PBV dengan nilai maksimum dan minimum yang cukup besar dari $0.13 \mathrm{~s} / \mathrm{d} 3.84$ menunjukkan bahwa PBV antar perusahaan bervariasi cukup tinggi. Sedangkan nilai standar deviasi antar perusahaan-perusahaan tersebut sebesar 0.96220 .

- Selama periode tahun 2008-2012 tingkat suku bunga (IR) yang berlaku rata-rata adalah sebesar 0.072 sedangkan tingkat IR yang terendah sebesar 0.06 yaitu pada tahun 2012. Tingkat suku bunga tertinggi adalah sebesar 0.09 yaitu pada tahun 2008. Tingkat standar deviasi suku bunga selama periode pengamatan sebesar 0.00987 .

Dari output SPSS di atas maka dapat terlihat bahwa hasil perhitungan nilai koefisien determinasi (R2) adalah sebesar 0.638. Hal ini menunjukkan bahwa pengaruh variabel independen yaitu ROE, DER, FATO, PBV dan IR terhadap variabel dependen yaitu PER yang dapat diterangkan dalam persamaan ini adalah sebesar $63.8 \%$ dan sisanya sebesar 36. 2\% dipengaruhi oleh faktor-faktor lain yang tidak ditermasuk ke dalam model regresi.

Tabel 4

Hasil Uji Hipotesis

\begin{tabular}{lrrrrr}
\hline Model & $\begin{array}{c}\text { Unstandardized } \\
\text { Coefficients B }\end{array}$ & Std. Error & $\begin{array}{c}\text { Standardized } \\
\text { Coefficients } \\
\text { Beta }\end{array}$ & $\mathbf{t}$ & Sig. \\
\hline 1 (Constant) & 20.402 & 7.253 & & 2.813 & .007 \\
ROE & -24.257 & 13.699 & -.206 & -1.771 & .083 \\
DER & .895 & 1.059 & .077 & .846 & .402 \\
FATO & -0.81 & .048 & -.173 & -1.694 & .097 \\
PBV & 6.289 & .817 & .717 & 7.699 & .000 \\
IR & -191.509 & 88.223 & .224 & -2.171 & .035 \\
\hline
\end{tabular}

a. Dependent Variable : PER

Pada hipotesis pertama selama periode 2008-2012 menunjukkan bahwa pengaruh dari semua variabel independen secara simultan terhadap variabel dependen yaitu Price Earning Ratio (PER). Hal tersebut menunjukkan bahwa PER sebetulnya dipengaruhi oleh kondisi fundamental perusahaan dan perkembangan makro ekonomi. Sedangkan ROE menunjukkan tidak berpengaruh signifikan terhadap PER Nilai ROE yang semakin tinggi menunjukkan bahwa tingkat pengembalian yang diharapkan investor juga makin tinggi dan investor akan mengapresiasi dengan angka PER yang semakin tinggi. Namun jika harga saham merefleksikan kapitalisasi laba yang diharapkan di masa yang akan datang maka peningkatan tersebut akan mengakibatkan penurunan PER. Harapan pihak investor dengan harga saham yang rendah maka potensi kenaikan harga saham dengan di masa yang akan datang akan semakin tinggi sehingga mereka memilih berinvestasi pada perusahaan dengan PER yang lebih rendah. Di sisi lain dampak krisis global pada tahun 2008 mengakibatkan pasar modal pada waktu itu semakin melemah sehingga kenaikan laba perusahaan pada periode berikutnya tidak diapresiasi oleh pihak investor dengan kenaikan PER. Hasil temuan ini mendukung 
hasil penelitan dari Yumettasari, et.al (2006), Aji dan Pangestuti (2012) yang menyatakan bahwa ROE berpengaruh signifikan terhadap PER namun bedanya dalam penelitian ini pengaruhnya tidak signifikan. Penelitian ini bertolak belakang dengan Mpaata dan Sartono (1997), Kurniawan (2005), Wiwin, et.al (2005), Hayati (2009) dan Faizinia (2012).

Hasil selanjutnya juga menujukkan bahwa Debt to equity ratio (DER) tidak berpengaruh signifikan terhadap PER. Hal ini disebabkan oleh peluang pertumbuhan perusahaan yang diproyeksikan tinggi sehingga penambahan hutang dalam struktur modal akan memberikan keuntungan. Disisi lain perusahaan-perusahaan yang bergerak di sektor properti dan real-estate membutuhkan pendanaan yang cukup besar untuk membiayai proyek-proyeknya sehingga cukup lazim untuk menarik pinjaman baik melalui bank melalui kredit maupun pasar modal dengan penerbitan obligasi. Hal ini akan menimbulkan toleransi pihak investor sehingga persepsi investor terhadap harga saham perusahaan tidak akan banyak berubah akibat kenaikan DER sehingga tidak berpengaruh terhadap PER. Hasil temuan ini mendukung hasil penelitian dari Arisona (2013) \& Aji dan Pangestuti (2012). Kemudian hasil penelitian ini bertolak belakang dengan Kurniawan (2005), Wiwin (2005), Yumettasari, et.al (2006), Kulling \& Lunberg (2007), Kumar Sushil \& Warne (2009), Hayati (2009) dan Faizinia (2012).

FATO tidak berpengaruh signifikan terhadap PER. Semakin tinggi angka FATO menunjukkan bahwa perusahaan mempunyai prospek yang baik sebab dengan penjualan yang positif diharapkan laba perusahaan semakin meningkat dan akan diapresiasi oleh pihak investor dengan harga per lembar saham yang semakin tinggi sehingga angka PER juga akan semakin tinggi. Namun disisi lain kenaikan aktiva tetap perlu direview lebih lanjut apakah berasal dari penjualan aktiva tetap yang menyebabkan penurunan denominator pada rasio FATO .Pada periode pengamatan tahun 2008 terjadi krisis ekonomi dunia yang berdampak pada IHSG sehingga pihak investor tidak begitu menganggap kenaikan atau penurunan angka FATO terhadap perusahaan sehingga angka FATO tidak berpengaruh terhadap PER. Hasil temuan ini mendukung hasil penelitan dari Hamidah (2010) dan Mpaata \& Sartono (1997).
PBV berpengaruh signifikan terhadap PER. PBV dapat merefleksikan nilai perusahaan sehinggapihakinvestorakantertarikberinvestasi pada perusahaan yang mempunyai rasio PBV yang tinggi. Hasil penelitian ini memberikan informasi bahwa semakin tinggi rasio PBV maka nilai perusahaan semakin meningkat sehingga membuat pihak investor tertarik untuk berinvestasi pada perusahaan property \& real estate yang akan berdampak pada peningkatan harga per lembar saham di pasar modal dan pada akhirnya akan meningkatkan rasioPER. Dengan demikian PBV berhubungan secara signifikan dengan arah positif terhadap PER. Hasil temuan ini mendukung hasil penelitian dari Aji \& Pangestuti (2010) namun bertolak belakang dengan hasil penelitian dari Hayati (2009).

Pada hipotesis keenam selama periode 2008-2012 menunjukkan bahwa IR berpengaruh signifikan terhadap PER. Sebagian besar penjualan properti \& real estate adalah dengan menggunakan skema kredit yang sangat berkaitan dengan pergerakan suku bunga (interest rate). Jika suku bunga rendah maka akan mendorong pembeli untuk melakukan pembelian properti sehingga akan mendorong kenaikan penjualan yang diharapkan akan meningkatkan laba perusahaan sehingga dapat mendorong EPS \& akan diapresiasi oleh pihak investor dengan kenaikan PER dan sebaliknya Dengan demikian IR berhubungan secara signifikan dengan arah negatif terhadap PER. Hasil temuan ini mendukung hasil penelitian dari Faezinia (2012), Kulling \& Lunberg (2007) dan Amoako-Adu \& Smith (2002) dan Beaver \& Morse (1978).

\section{Simpulan, Keterbatasan, dan Implikasi Hasil Penelitian}

Berdasarkan hasil penelitian kemudian rangkaian olah data dan analisis serta pembahasan mengenai pengaruh variabel ROE, DER, FATO, PBV dan IR terhadap price earning ratio (PER) maka dapat ditarik beberapa kesimpulan, antara lain sebagai berikut:

1. Berdasarkan hasil pengujian hipotesis pertama menunjukkan bahwa seluruh variabel bebas secara simultan berpengaruh signifikan terhadap Price Earning Ratio (PER), hal tersebut sudah sesuai dengan hipotesisnya yang menyatakan bahwa variabel-variabel independen secara 
simultan berpengaruh terhadap PER sebab Price Earning Ratio (PER)

2. Berdasarkan hasil pengujian hipotesis kedua menunjukkan bahwa ROE tidak berpengaruh signifikan terhadap PER, hal ini tidak sesuai dengan hipotesis yang menyatakan bahwa ROE berpengaruh signifikan terhadap PER.

3. Berdasarkan hasil pengujian hipotesis ketiga menunjukkan bahwa DER tidak berpengaruh secara signifikan terhadap PER, hal ini tidak sesuai dengan hipotesis yang menyatakan bahwa DER berpengaruh secara signifikan terhadap PER.

4. Berdasarkan hasil pengujian hipotesis keempat menunjukkan bahwa FATO tidak berpengaruh secara signifikan terhadap PER, hal ini tidak sesuai dengan hipotesisnya yang menyatakan bahwa FATO berpengaruh secara signifikan terhadap PER.

5. Berdasarkan hasil pengujian hipotesis kelima menunjukkan bahwa PBV berpengaruh secara signifikan terhadap PER, hal ini sesuai dengan hipotesisnya yang menyatakan bahwa PBV berpengaruh secara signifikan terhadap PER.

6. Berdasarkan hasil pengujian hipotesis keenam menunjukkan bahwa IR berpengaruh secara signifikan terhadap PER, hal ini sesuai dengan hipotesisnya yang menyatakan bahwa IR berpengaruh secara signifikan terhadap PER.

Penelitian ini memiliki sejumlah keterbatasan-keterbatasan, diantaranya adalah sebagai berikut:

1. Periode penelitian yang digunakan masih cukup terbatas (2008-2012)

2. Penelitian ini menggunakan sample perusahaan yang bergerak di sektor properti $\&$ real estate.

3. Penelitian ini menggunakan 4 variabel fundamental yaitu ROE, DER, FATO, PBV dan 1 variabel makro ekonomi yaitu interest rate.

4. Mengabaikan faktor psikologis investor.

Berdasarkan kesimpulan dan keterbatasan penelitian yang telah disampaikan dan analisis data dia atas maka penulis mengajukan saran-saran sebagai berikut:

1. Investor dalam memilih investasi saham di perusahaan di sektor properti \& real estate sebaiknya memilih perusahaan dengan kondisi fundamental dan makro ekonomi yang baik yaitu ROE, PBV dan IR.

2. Menambah rentang waktu penelitian yang lebih lama.

3. Penelitian berikutnya perlu perlu menambah sektor-sektor lain yang terdapat di BEI. Kemudian perlu ditambahkan \& variabel makro ekonomi selain variabel di atas.

4. Perlu diperhatikan juga faktor psikologis investor sebab harga saham merupakan faktor yang sangat menentukan PER sementara pergerakan harga saham sangat dipengaruhi oleh persepsi investor terhadap perusahaan yang akan diikuti oleh para investor yang lain. Hal ini sesuai dengan fenomena bias psikologi anchoring yang dikemukakan oleh Kahneman \& Tversky dalam Atmaja \& Hikmat (2014).

\section{Daftar Pustaka}

Abdurrakhman, 2012, Pengaruh Current Ratio, Return on Equity, Total Asset Turnover, dan Size Terhadap Price Book Value (Studi Empiris Pada Perusahaan Consumer Goods yang Terdaftar di Bursa Efek Indonesia Periode 2006-2010), Tesis, Magister Akuntansi, Universitas Pancasila, Jakarta.

Adi, A. 2013, Pengaruh Return On Equity, Debt To Equity Ratio, Earning Per Share Dan Book Value Per Share Terhadap Harga Saham (Studi pada Perusahaan Consumer Goods Industry yang Terdaftar di BEI Periode Tahun 2008-2011). Jurnal Administrasi Bisnis, 4(2).

Adu, Amoaku, Smith, Brian, 2002, Analysis of $P / E$ Ratio and Interest Rate, Managerial Finance, Vol 28, ABI/Inform Global, Ontario, Canada.

Aji, Nurseto. M \& Pangestuti. D, 2012, Analisis Faktor-Faktor Yang Mempengaruhi Price Earning Ratio (Studi Empiris Pada Perusahaan Manufaktur yang Terdaftar di BEI 2007-2010), Universitas Diponegoro, Semarang

Arisona, F.V, 2013, Faktor-Faktor Yang Mempengaruhi Price Earning Ratio Pada Indeks $L Q 45$ di BEI, Universitas Negeri Surabaya.

Basu, S., 1975, The Information Content of Price Earning Ratio, Financial Management, Vol 4, USA

Basu, S., 1977, The Investment Performance of Common Stocks in Relationship to Their Price Earning Ratio, Journal of Finance, USA

Beaver, William B, 1978, The Information 
Content of Annual Earnings Announcements, Journal of Accounting Research

Brealey, R.,A., \& S.C. Myers, 2008, Principles of Corporate Finance, 9th Edition, Mc Graw-Hill, Inc, New York.

Datar \& Banerjee, 2006, Determinants of Price Earning Ratios: A Study of Listed Firms in India, JEL, India

Faezinia, V, et. al, 2012, The Quantitative Study of Effective Factors on Price Earning Ratio in Capital Market in Iran, IJCRB, Vol.3 No 10, Iran

Fama, Eugene F, 1970, Efficient Capital Markets: A Review of Theory and Emprical Work, Journal of Finance 25, University of Chicago, USA

Ghozali, Imam, 2006, Aplikasi Analisis Multivariate Dengan SPSS, Universitas Diponegoro, Semarang.

Hamidah, Ratna.D , 2010, Analisis FaktorFaktor Yang Mempengaruhi Price Earning Ratio (Studi Empiris Pada Perusahaan Manufaktur yang Terdaftar di BEI 2004-2007),Skripsi, Universitas Muhammadiyah Yogyakarta

Harjito, Agus, 2012, Dasar-Dasar Teori Keuangan, Edisi Pertama, Penerbit Ekonisia, FE-UII, Yogyakarta

Hayati, Nurul, 2010, Faktor-Faktor Yang Mempengaruhi Price Earning Ratio (PER) Sebagai Salah Satu Kriteria Keputusan Investasi Saham Perusahaan Real Estate \& Property di Bursa Efek Indonesia, Vol 11, STIE Banjarmasin - Banjarmasin.

Ikatan Akuntan Indonesia (IAI), 2012, Standar Akuntansi Keuangan (per 1 Juni 2012)", Penerbit Salemba Empat, Jakarta.

Jogiyanto H., 2000, Teori Portofolio dan Analisis Investasi, Edisi Kedua, BPFE, Yogyakarta.

Jogiyanto H., 2010, Teori Portofolio dan Analisis Investasi, Edisi Ketujuh, BPFE, Yogyakarta.

Kurniawan, Fery, 2005, Analisis Faktor-Faktor Yang Mempengaruhi Price Earning Ratio Saham Perusahaan Manufaktur di Bursa Efek Jakarta 2001-2003, Tesis, Magister Manajemen, Universitas Diponegoro, Semarang.

Kulling J.K., dan Lundberg, Filip, 2007, A Quantitative Study of P/E Ratio on The Swedish Market, Thesis, University Essay From Lunds Universitet, Department of Economis, Swedish.
Markus, Kane, Bodie, 2009, Investment, 6nd Edition, Buku Dua, Edisi Bahasa Indonesia, Penerbit Salemba Empat, Jakarta.

Mpaata, A.K., dan Sartono, Agus 1997, Factor Determining Price Earning (P/E) Ratio, Kelola, Yogyakarta

Nicolson, Francis, S., 1960 Price-Earning Ratio, Jurnal International, USA

Palepu, G. Krishna, et.al, 2010, Business Anaysis and Valuation IFRS Edition, 2nd Edition, South-Western Cengage Learining, United Kingdom

Rose, Marquis, 2006, Money and Capital Markets : Financial Institutions and Instruments in Global Marketplace, Ninth Edition, McGraw-Hill Internaltional Edition, New York, USA.

Saerang, David \& Pontoh, Winston, 2011, Analisis Pengaruh Tingkat Pengembalian Aktiva Terhadap Harga Saham Perusahaan di BEI (Studi Pada Saham Perusahaan LQ45 Periode 2004 s/d 2008), Jurnal Riset Akuntansi \& Auditing, Maksi FE-Unsrat, Vol 2 No. 2, Manado.

Tambunan, Porman, Andy, 2007, Menilai Harga Wajar Saham, Cetakan Ketiga, PT Elex Media Komputindo, Jakarta.

Tian \& Zheng, 2006, Empirical Study on The Main Factors Affecting Price Earning Ratio of Listed Companies in China, Henan Polytechnic University, China

Warne, Sushil, Kumar, 2009, Determinants of Price-Earning Ratio in India Capital Market, IUP Journal of Appliaed Finance, India

Whitbeck, V \& Kissor, M, 1963, A New Tool in Investment Decision Making, Financial Analysis Journal, USA

Widyastuti, Indriyana, 2008, Efisiensi Pasar Modal Sebagai Alat Analisis Sekuritas, Jurnal, STIE AUB Surakarta, Solo.

Wiwin, dan Eko, 2005, Faktor-Faktor Yang Mempengaruhi Price Earning Ratio Pada Perusahaan Yang Terdaftar di Bursa Efek Jakarta, Vol. 5, No. 2, Jurnal Bisnis \& Manajemen, Solo

Yumettasari, et.al, 2008, Analisis Faktor-Faktor Yang Mempengaruhi PER Antara Saham Syariah \& Saham Non Syariah, Universitas Diponegoro, Semarang 